\title{
Wisdom begins in wonder
}

\author{
A sabedoria começa na reflexão
}

(Socrates, 470-399 BC.)

$\Omega$

The critical perception of the ophthalmologic scope for national scientific journals raises constant search for improvement and adjustment to the editorial needs. The publishing process currently proposed by Sociedade Brasileira de Oftalmologia (SBO) aims at aspects to facilitate the submission of articles by the authors, help revisers, and mainly satisfy the desires of the readers, increasingly demanding. In this editorial we share the analysis of a series of modifications and their results for the last two years of the current Board of Directors.

Revista Brasileira de Oftalmologia (RBO) has published 12 consecutive numbers in two volumes during the period from January 2015 to December 2016. The regularity in the editorial process by sending the files to index databases (SciELO and SCOPUS/SCimago) within the deadlines, and even before (Ahead of Print) was considered one of the most important results. This was made possible by the reduction in the editorial process to publish original articles in approximately 3 months. The changes in the digital platform of RBO and its cloud system with the simplification of the whole process of peer review directly influenced this time. Digital restructuring also started to use all the text in XML version (eXtensible Markup Language), which facilitates the network information sharing necessary to obtain the Digital Object Identifier (DOI) registered in the CrossRef base. The DOI developed by the American Publishers Association identifies, locates and authenticates each article available on the internet.

In addition to try to adjust the amount of articles to the scientific criteria recommended by the SciELO collection for health, we also restructured the format of the summary in accordance with the guidelines of Pubmed/Medline, in order to apply for future indexing, which happens to be eligible next year.

RBO has had a progressive increase in access in recent years, being more significant from March $2015^{(1,2)}$. The increased demand from readers was for original articles, representing a total of approximately $70 \%$ of all articles surveyed $^{(1)}$. These data confirm both the increasing interest in the agenda of the issues published in the RBO and the recognition by the scientific rigor that the magazine has adopted, since more than one third of the articles sent for submission has been rejected ${ }^{(3)}$.

Among the many criteria for evaluation of scientific journals, the citation of the articles is considered one of the greatest importance. The greater the number of articles cited on a periodical, the greater its influence in academia. The citation of the journal is even more important when it is made by articles published in other journals. In addition to the total increase in citation in the last years, we have seen more recently an increasing proportion of external citations regarding self-citations, in the order of $50 \%{ }^{(2)}$, the greatest of all historical series of RBO since its inclusion in ScieLO. These numbers reflect a more active and in evidence RBO, which is confirmed by analyzing ScieLO Citation Index for the last 2 years (base 2016) which scored 0.0559 and 0135 according to Scimago Journal \& Country Rank ${ }^{(1,2)}$. These numbers still need to be improved to meet the standards of the leading international journals. 
The transmission of knowledge involves different forms of education, which in the editorial process can be observed primarily through the critical analysis made by the revisers of the papers submitted, always trying to guide, discuss and enhance their scientific quality. The involvement and commitment of the editorial board were crucial for the improvement observed and the growth of RBO. We report here our sincere thanks.

There are those that look at things the way they are, and ask why? I dream of things that never were, and ask why not?

(Robert Kennedy, 1925-1968)

André Luis Freire Portes

Associate professor of Ophthalmology at the Medicine School of Universidade Estácio de Sá (UNESA- RJ) Doctor of Sciences of the Ophthalmology Program at the MedicineSchool of Universidade de São Paulo (USP-SP)

Editor-in-Chief of Revista Brasileira de Oftalmologia (2015-2016)

\section{RefERENCES}

1. Scieloanalytics. [Internet]. [cited 2016 Oct 10]. Availablefrom: http://analytics.scielo.org/w/accesses?journal=0034-7280\&collection=scl

2. SJR ScimagoJournal\& Country Rank. [Internet]. [cited 2016 Oct 10]. Availablefrom: http://www.scimagojr.com/journalsearch.php?q=15100 \& tip $=$ sid \& clean $=0$

3. Portes AL. Só fazemos melhor aquilo que repetidamente insistimos em melhorar... RevBras Oftalmol. 2016;75(3):173. 